\title{
A 39-year-old woman with spots covering her body
}

\author{
David Cowart, ${ }^{1}$ Kimberly A Cowart, ${ }^{2}$ Firas G Hougeir ${ }^{2}$
}

1 Department of DOHET, Tripler Army Medical Center, Tripler AMC, Hawaii, USA

${ }^{2}$ Department of Dertmatology, Family Dermatolgoy, Douglasville, Georgia, USA

\section{Correspondence to} Dr David Cowart, david.w. cowart@us.army.mil

\section{DESCRIPTION}

A 39-year-old African-American woman presented with a 12-year history of 'itchy dark spots all over my body, excluding the face and acral surfaces. The lesions are slightly pruritic at baseline. Flares occur frequently, however, mostly with friction of drying off with a towel, resulting in urtication and increased pruritus of the skin lesions. The patient has similar flares with alcohol ingestion. The patient also reports chronic diarrhoea and headaches which began at approximately the same time she developed the skin lesions. Two previous colonoscopies and endogastroduodenoscopies were unremarkable. Evaluation by her primary care physician showed no identifiable cause for her headaches; a head CT was unremarkable. The headaches were treated with naproxen, causing flushing and palpitations; a cardiovascular workup was unremarkable. She additionally has chronic 'achy' bone pain in her thighs.

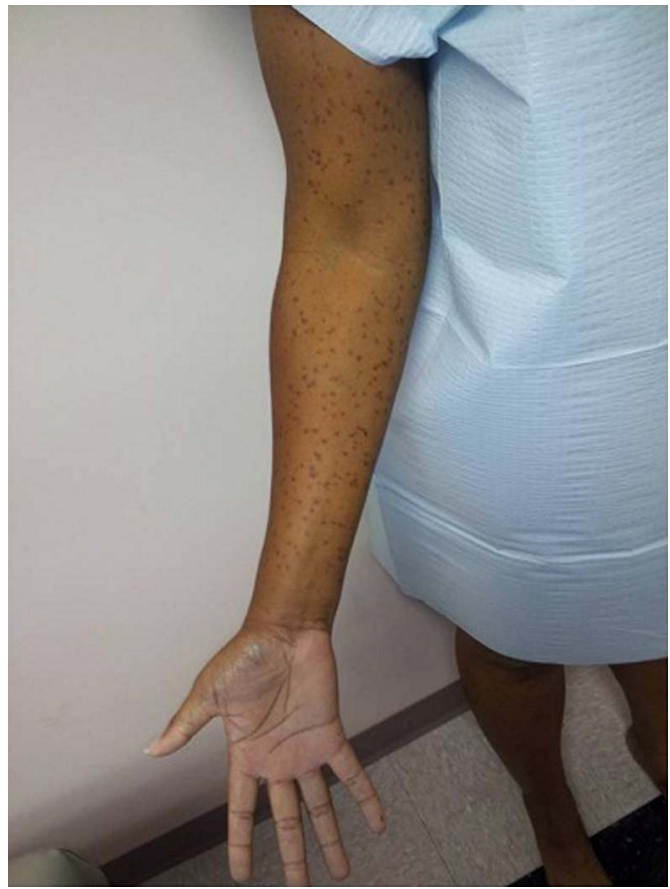

Figure 1 Numerous small 1-2 mm well-circumscribed hyperpigmented macules and papules distributed over extremities and trunk.

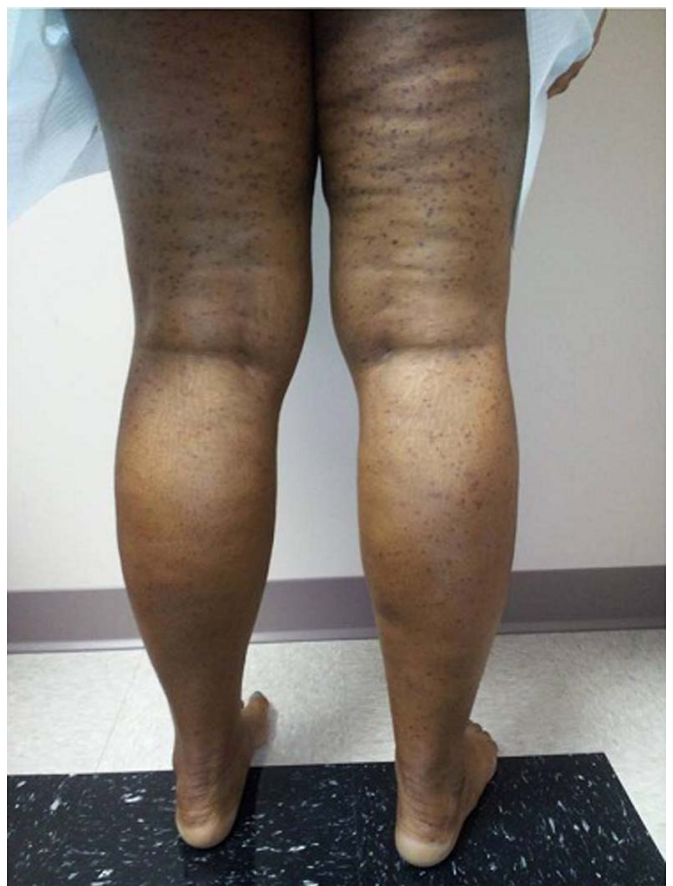

Figure 2 Numerous small 1-2 mm well-circumscribed hyperpigmented macules and papules distributed over extremities and trunk.

All of the aforementioned symptoms are exacerbated by exercise, heat, non-steroidal antiinflammatory drugs, alcohol and narcotics. She denies any formation of blisters and the review of systems is otherwise unremarkable. She uses diphenhydramine and fexofenadine which decreases the severity of her symptoms. The patient is otherwise healthy with no family history of similarly affected individuals. She takes no scheduled medications and has no known allergies.

Skin examination reveals numerous similar appearing diffusely scattered 1-2 mm, wellcircumscribed pigmented macules and papules (figures 1 and 2). No lymphadenopathy or organomegaly was present. Pertinent laboratory values, including a complete blood count, comprehensive metabolic panel and lactate dehydrogenase are within normal limits. Rubbing the skin causes urtication of the pigmented macules. 


\section{Learning points}

- Urticaria pigmentosa is a form of mastocytosis (tissue mast cell hyperplasia) that occurs most commonly in adults, reported mostly in white patients. Mast cells are released from the bone marrow and circulate in the blood as agranular, monocytic-appearing cells. Following their migration into tissue, they assume their typical granular morphology. Many forms of mastocytosis involve an activating mutation on codon 816 of the c-KIT proto-oncogene, ${ }^{12}$ whose ligand is stem cell factor (SCF). KIT is expressed on many cell types, including mast cells, melanocytes and osteocytes among others. This activating mutation in KIT induces cellular growth and inhibits apoptosis. ${ }^{2}$ The SCF accumulates in tissues and stimulates certain cells, to include melanocytes, which is the likely cause of the hyperpigmented cutaneous macules.

- The skin is the most frequent organ involved and stimulation of the accumulated mast cells causes histamine release. Cutaneous symptoms can include pruritus, flushing and urticaria. Symptoms such as headache, cramping, diarrhoea, epigastric pain, nausea, chest pain, dizziness, palpitations, syncope and bone pain are clues of possible extracutaneous involvement. Extracutaneous involvement is more commonly seen in adulthood forms of mastocytosis. ${ }^{3}$

- Common triggers in disorders of mastocytosis include exercise, heat, trauma, alcohol, narcotics, non-steroidal anti-inflammatory drugs, anticholinergic medications, as well as hymenoptera stings. Diagnosis is made through a thorough history and physical examination with a confirming skin biopsy. Pathological evaluation of a lesion in our patient showed increased mast cells in the papillary dermis with positive immunostains. Darier's sign (stroking lesions result in urtication) may or may not be present. There is no cure for mastocytosis and treatment is generally targeted at avoiding triggers and treating symptoms. The cutaneous lesions respond well to topical steroids and if signs or symptoms of systemic involvement are present the patient should be treated with $\mathrm{H} 1 / \mathrm{H} 2$ blockers. If the patient has severe systemic involvement, there have been promising outcomes with the use of interferon- $\alpha$, cladribine, imatinib mesylate and leukotriene modifying agents.

- Mastocytosis can have a highly variable presentation with or without skin findings or systemic involvement and can therefore be a very difficult diagnosis to make clinically. Early recognition of this disease is aided by a careful history of unresolving chronic symptoms and cutaneous lesions, which should be biopsied. In addition to a complete blood count with differential and liver function tests, a serum tryptase elevation can be helpful in establishing the diagnosis and a bone marrow biopsy should be obtained in all adults with mastocytosis as systemic disease is more common in this population. Measurement of $N$-methyl histamine and 11- $\beta$-prostaglandin F2, which are metabolites of mast cell activation, may also be elevated.
Contributors DC, FGH and KAC had full access to all the data in the case study and take responsibility for the integrity of the data; and were involved in drafting the manuscript.

Competing interests None.

Patient consent Obtained.

Provenance and peer review Not commissioned; externally peer reviewed.

\section{REFERENCES}

1 Zappulla JP, et al. Mastocytosis in mice expressing human KIT receptor with the activationg Asp816Val mutation. J Exp Med 2005;202:1635-41.

2 Fett NM, Teng J, Longley BJ. Familial urticaria pigmentosa: report of a family and review of the role of KIT mutations. Am J Dermatopathol 2013;35:113-16.

3 Berezowska S, Flaig MJ, Rueff F, et al. Adult-onset mastocytosis in the skin is highly suggestive of systemic mastocytosis. Mod Pathol 2013;10:1038. 
Copyright 2013 BMJ Publishing Group. All rights reserved. For permission to reuse any of this content visit http://group.bmj.com/group/rights-licensing/permissions.

BMJ Case Report Fellows may re-use this article for personal use and teaching without any further permission.

Become a Fellow of BMJ Case Reports today and you can:

- Submit as many cases as you like

- Enjoy fast sympathetic peer review and rapid publication of accepted articles

- Access all the published articles

- Re-use any of the published material for personal use and teaching without further permission

For information on Institutional Fellowships contact consortiasales@bmjgroup.com

Visit casereports.bmj.com for more articles like this and to become a Fellow 